\title{
AOR
}

Selected Papers of \#AolR2021:

The 22nd Annual Conference of the

Association of Internet Researchers

Virtual Event / 13-16 Oct 2021

\section{THE IMAGINED INDEPENDENCE OF THE CANADIAN INTERNET}

\author{
Kayla Hilstob \\ Simon Fraser University

\section{Background and Context}

Internet scholars are uncovering and connecting military, political and cultural histories of early internets across the globe, including in the US, (Abbate 1999), Chile (Medina 2011) and France (Mailland \& Driscoll 2016), respectively. All three approaches inform this exploration of the Canadian context, an internet history that has been underexplored. The internet came to Canada as we know it today in 1989 through NetNorth, a private communication network developed by academics and researchers in 1983, where it eventually opened to the public and adopted protocols that originated with ARPANET (Miller 2015). But the history of the Canadian internet begins decades earlier, in 1965 when the Communication and Electronics branch of the Canadian Armed Forces (CAF) first commissioned a study to develop, build, and implement its own internet. The concept was informed by the close relationship to the United States military through NORAD, where a top-secret whitepaper first recommended Canada develop a distributed communications network (NORAD 1965), following Paul Baran's (1964) publication on the subject one year previous. Subsequently, Project SAMSON: Strategic Automatic Message Switching Operational Network was convened to modernize and secure its outdated communication system, an early internet that experienced a series of serious setbacks beginning almost immediately, until it was disbanded in 1984.

The early emergence of the Canadian internet occurred at a time of political renewal. The charismatic and popular figure Pierre Trudeau led this renewal in many ways during his tenure as Prime Minister from 1968-1984 (with a brief hiatus in 1980). At this time, Canada attempted to construct its own independent national identity separate from the United States and its British colonial roots (Litt 2008). As the name of Canada's first civilian internet, NetNorth, suggests, Canada's internet imaginary stands unavoidably in relation to the United States, an occurrence endemic to the wider context of Canada US relations. As Pierre Trudeau famously stated in 1969, it is like "sleeping with an elephant. No matter how friendly and even-tempered the beast, if I can call it that, one is affected by every twitch and grunt" (CBC 2018). At a time of pushback against American influence, the Canadian military constructed SAMSON in a grand ambition to 
build a completely made-in-Canada system that was to be better than those of its allies, despite the technology and expertise not being available in Canada (Hatt 1984). It may have been this resistance to any American influence that led Canada's internet to fail, and paradoxically made Canada eventually more technologically dependent on the Unites States following its complete integration with ARPANET.

\section{Research Question and Methods}

This paper investigates Canada's internet infrastructural technopolitics through Larkin's framework of questioning how they "emerge out of and store within them forms of desire and fantasy and can take on fetish-like aspects" $(2013,329)$. Specifically, it addresses how the design, equipment, and network protocols of the Canadian internet embodied the imaginary of Canadian independence, and how this history can be found in internet infrastructure today. Drawing on the scholarship of infrastructure studies, this paper examines political imaginaries that are recycled and transmitted through technology. Using Winner's (1980) perspective of infrastructure as the materiality of politics, I interpret how internet infrastructure, real or imagined, mutually constitute and affect social, political and economic arenas in society.

This paper examines internet infrastructure from 1965 to 1984, attentive to Canada's rejection of both cooperation with the United States in developing its internet and Baran's recommendation for a distributed network on the grounds of concern not of nuclear survivability, but of internal threats: "civil unrest, sabotage and subversion" (CAF 1985). I draw on primary sources from the unpublished documents from the Directorate of History and Heritage archives. The materials come from the Communications and Electronics branch of the CAF that were declassified between 1997-2003. These documents include reports, studies, contracts, meeting minutes, memoranda and newspaper clippings.

\section{Research Implications}

Internet infrastructure typically undergoes periods of localized state control and open distribution across networks (Thussu 2018). In examining Canada's course between fragmentation and integration, analysis of decisions about geopolitics and security sheds light on global surveillance mechanisms that today's internet users have inherited. As scholars visit questions of future conflicts around internet fragmentation (Mueller 2015), this history further clarifies that disintegration is not novel but a part of internet history and decisions about internet infrastructure can be revisited in the interest of a more equitable distribution of power.

SAMSON was oriented towards securing the state against those who were seen as an internal threat, namely Indigenous peoples. By design the Canadian internet was a security apparatus, but the technopolitics embedded in the system dictate who is to be secured against whom. Indigenous peoples have always been surveilled by the federal government through the use of technology, historically through Indian Status Act cards, the reserve pass system, or Inuit numbered discs, for example (Proulx 2014). Even at a time when the Canadian internet was merely an idea, this threat was identified and prioritized over Cold War rivalries. This history provides additional insight into today's 
surveillance regimes, with its history traceable even to the first feasibility study of a Canadian digital communications network. Though with now different protocols, the technopolitics of Canada's internet remain, informing current participation in the Five Eyes intelligence alliance, and anti-terror legislation that permits lawful digital surveillance on everyone, particularly targeting activists and Indigenous-led movements.

\section{References}

Abbate, J. (2000). Inventing the internet. MIT Press.

Baran, P. 1964. "On Distributed Communications: I. Introduction to Distributed Communications Networks". The RAND Corporation. Santa Monica: CA.

Canadian Armed Forces Communication and Electronics Branch. 1985. "SAMSON Project Narrative". September 3, 1985. Catherine Allan Fonds, The Directorate of History and Heritage, Ottawa, ON.

CBC. 2018. "Sleeping with a Very Cranky Elephant: The History of Canada-U.S. Tensions". CBC Radio. June 15 2018. Retrieved from https://www.cbc.ca/radio/sunday/the-sunday-edition-june-17-20181.4692469/sleeping-with-a-very-cranky-elephant-the-history-of-canada-u-stensions-1.4699017

Hatt, W. L. 1984. "Project SAMSON: Strategic Automatic Message Switching Operational Network Project Completion Report". Canadian Armed Forces Communication and Electronics Branch. April 1984. Catherine Allan Fonds, The Directorate of History and Heritage, Ottawa, ON. Declassified Nov 271997.

Larkin, B. 2013. "The Politics and Poetics of Infrastructure". Annual Review of Anthropology 42: 327-343.

Litt, P. 2008. "Trudeaumania: Participatory Democracy in the Mass-Mediated Nation". Canadian Historical Review 89 (1): 27-53.

Mailland, J. and K. Driscoll. 2016. Minitel: Welcome to the Internet. MIT Press.

Medina, E. 2011. Cybernetic Revolutionaries: Technology and Politics in Allende's Chile. MIT Press.

Mueller, Milton L. 2017. Will the Internet Fragment? Cambridge, MA: Polity Press.

Miller, G. 2015. “A Birthday for Canada's Internet”. Canarie. November 6, 2015 https://www.canarie.ca/a-birthday-for-canadas-internet/

NORAD. 1965. "Brief for VCDS". North American Air Defense Command. April 1965. Catherine Allan Fonds, The Directorate of History and Heritage, Ottawa, ON. Declassified May 29, 2003. 
Proulx, C. 2014. "Colonizing Surveillance: Canada Constructs an Indigenous Terror Threat," Anthropologica 56 (1):83-100.

Thussu, Daya. 2018. International Communication: Continuity and Change. New York, NY: Bloomsbury Academic.

Winner, L. 1980. “Do Artifacts Have Politics?” Daedalus 109 (1): 121-36. http://www.jstor.org/stable/20024652. 